\title{
Pilgrims in Old Uyghur Inscriptions: A Glimpse behind Their Records
}

\author{
Simone-Christiane Raschmann
}

\section{Introduction}

The remains of Old Uyghur Buddhist scriptures of varying content, as well as records and documents of Buddhist communities and monasteries which are preserved in numerous Central Asian collections worldwide, clearly demonstrate the widespread and fairly long-lasting Buddhist orientation of the Uyghurs and their affiliation to different Buddhist schools or varieties of Buddhism. ${ }^{1}$ In addition, colophons added to the copies of Buddhist texts and cartouches added to Buddhist wall paintings deliver information on translators, writers, readers and sponsors. ${ }^{2}$ Finally, a significant number of Old Uyghur inscriptions were left by pilgrims at various sites. But, as far as we know today, indigenous records on Buddhist pilgrimages like those of the famous Chinese Buddhist monastic travellers Faxian (ca. 340-before 423, 法顯), Xuanzang (60o/602-664, 玄奘), and others, are just as limited as manuals or descriptive itineraries for pilgrimage in Old Uyghur Buddhist literature. ${ }^{3}$

1 Cf. amongst others, Jens Wilkens, "Buddhismus bei den türkischen Völkern Zentralasiens," in Der Buddhismus II: Theravada-Buddhismus und tibetischer Buddhismus, ed. Manfred Hutter (Stuttgart: Verlag W. Kohlhammer, 2016), 469-49o; Jens Wilkens, "Buddhism in the West Uyghur Kingdom and Beyond," in Transfer of Buddhism Across Central Asian Networks (7th to 13th Centuries), ed. Carmen Meinert (Leiden, Boston: Brill 2016), 191-249; Peter Zieme, "The West Uigur Kingdom: Views from Inside," Horizons 5.1 (2014): 1-29; Peter Zieme, "Uighur Buddhism," in Oxford Bibliographies: Buddhism, ed. Richard Payne (New York: Oxford University Press, 2014), accessed September 18, 2018. doi: 10.1093/obo/978o195393521-o197; Peter Zieme, "Local Literatures: Uighur," in Brill's Encyclopedia of Buddhism. Vol. I. Literature and Languages, ed. Jonathan A. Silk et al. (Leiden, Boston: Brill, 2015), 871-882.

2 Peter Zieme, Religion und Gesellschaft im Uigurischen Königreich von Qočo. Kolophone und Stifter des alttürkischen buddhistischen Schrifttums aus Zentralasien (Opladen: Westdeutscher Verlag, 1992); BT xxvI.

3 For an interesting discussion concerning questions such as whether the Chinese pilgrim records form a consistent genre of their own or whether the documents they produced should no longer be called pilgrims' records, see Max Deeg, "When Peregrinus is not Pilgrim: The Chinese "Pilgrims"' Records-A Revision of Literary Genre and its Context," in Searching for the Dharma, Finding Salvation:Buddhist Pilgrimage in Time and Space, ed. Christoph Cueppers and Max Deeg (Lumbini: Lumbini International Research Institute, 2014), 65-95. 
However, although very important initial steps have been taken in order to gain a better understanding of the Uyghur pilgrimage, a comprehensive and interdisciplinary study of the many different sources is still missing. Of course, such an undertaking would go beyond the scope of the present study. The present paper is restricted to

1. presenting the actual state of research on the basis of the scholarly literature;

2. surveying and evaluating the Old Uyghur pilgrim inscriptions from Dunhuang, Hohhot (in present Inner Mongolia) and the Turfan region; and

3. showing the potential of the interdisciplinary approach to the subject, using the example of ruin Q in Kočo.

\section{Uyghur Buddhist Pilgrimage}

Even though several details of the process are still under discussion, there seems to be general agreement that the substantial and long-lasting conversion from Manichaeism to Buddhism among the Uyghurs started in the late tenth century, after their migration to the west and their settlement in the eastern part of the Tianshan (天山), the Heavenly Mountains. Buddhist culture was present in this region from the first centuries of the Common Era onwards, and in its early stage Uyghur Buddhism was mainly influenced by Tokharian and Chinese Buddhism, the followers of which had been living in the territories of the newly founded West Uyghur Kingdom (second half 9th c. to 13 th c.) for a long time. The role of the Sogdians in this process is still under discussion. Without going into detail here, there exists conclusive evidence in the Old Uyghur Buddhist sources for this briefly outlined process. Starting in the 11th century at the latest, when most Uyghurs had converted to Buddhism already, Uyghur Buddhism underwent a broad and manifold development. Furthermore, because of the strong relations between Dunhuang and the West Uyghur Kingdom, the influence of Buddhism from Dunhuang had to be taken into account when considering the orientation of Uyghur Buddhism. ${ }^{4}$ It is thanks to

4 For more detailed information on this subject see, amongst others, Wilkens, "Buddhism in the West Uyghur Kingdom," 204-225; Takao Moriyasu, "Chronology of West Uighur Buddhism: Re-examination of the Dating of the Wall-Paintings in Grünwedel's Cave No. 8 (New: No. 18), Bezeklik," in Aspects of Research into Central Asian Buddhism: In Memoriam Kögi Kudara, ed. Peter Zieme (Turnhout: Brepols, 2008), 191-227; Xinjiang Rong, "The Relationship of Dunhuang with the Uighur Kingdom in Turfan in the Tenth Century," in De Dunhuang à Istanbul: Hommage à James Russell Hamilton, ed. Louis Bazin and Peter Zieme (Turnhout: Brepols, 2001), 275-298. 
the existence of a well-developed Old Uyghur scriptural culture that indigenous pilgrim inscriptions are available for collecting first-hand information concerning Uyghur pilgrimage, and since text philology is the author's primary field, the remarks concerning Uyghur pilgrimage will concentrate on the results of the studies of the preserved written sources. In the present context, it seems to be worth mentioning that the biography of the famous Chinese Buddhist monk and pilgrim Xuanzang is to be found among the Old Uyghur Buddhist scriptures translated from Chinese into Old Uyghur between the end of the 1oth and the beginning of the 11th century. This given date is closely connected to the known lifespan of its translator, Šijko Šäli Tutur (fl. second half of 11th c./beginning of 12th c.) from Beš Balık, whose Chinese or Uyghur descendance is still under discussion, as is the precise date of the translation. The Old Uyghur Xuanzang biography belongs to the first comprehensive Buddhist scriptures which were translated from Chinese into Old Uyghur, most probably under the deep influence of Dunhuang Buddhism. ${ }^{5}$ It goes without saying that pilgrims aim to visit, at least once in their lifetime, sacred places which are of extraordinary religious significance. Among the various sacred mountains of Chinese Buddhism, Mt. Wutai (Chin. Wutai shan 五台山) has an important role. Dunhuang was not just an important place for pilgrims on their road to Mt. Wutai, Chinese poems written in praise of this sacred mountain are known from the Dunhuang text findings. ${ }^{6}$ From the current state of research, one could conclude that no other versions of these poems existed if it were not for the Chinese versions known from Dunhuang. Furthermore, according to Peter Zieme, no translation of the famous Wutai shan zan五台山贊 [Praise of Mt. Wutai] in other languages of the Middle Ages other than Old Uyghur has been found (fig. 8.1)..$^{7}$ It is quite remarkable that the Praise of Mt. Wutai is attested

5 For an overview on the extensive literature on the Old Uyghur Xuanzang biography and the editions of its text, cf. Johan Elverskog, Uygur Buddhist Literature (Turnhout: Brepols, 1997), 131-135; Albet Semet, Lexikalische Untersuchungen zur uigurischen Xuanzang-Biographie (Wiesbaden: Harrassowitz, 2005), 1-31; BT XXVI, 144-147; Hakan, Aydemir, Die alttürkische Xuanzang-Biographie IX (Wiesbaden: Harrassowitz, 2013), 1-10.

6 Wilkens, "Buddhism in the West Uyghur Kingdom," 222; Peter Zieme, "Three Old Turkic Wutaishanzan Fragments," Nairiku ajia gengo no kenkyū 内陸アジア言語の研究 Studies on the Inner Asian Languages 17 (2002): 223-239; Peter Zieme, "Gudai Huigu fojiao zhi zhong de Wutai shan yu Wenshu shili 古代回鹘佛教之中的五台山与文殊师利 [Mt. Wutai and Mañjuśrī in Uyghur Buddhism]," in Yishan er wuding: Duo xueke, kua fangyu, chao wenhua shiye zhong de Wutai xinyang yanjiu一山而五顶：多学科、跨方域、超文化视野中的 五台信仰研究 [One Mountain of Five Peaks: Studies of the Wutai Cult in Multidisciplinary, Crossborder and Transcultural Approaches], ed. Miaojiang 妙江, Chen Jinhua 陳金華, and Kuanguang 寬廣 (Hangzhou: Zhejiang daxue chubanshe, 2017), 117-126.

7 Zieme, "Wutai shan yu Wenshu shili," 119. 


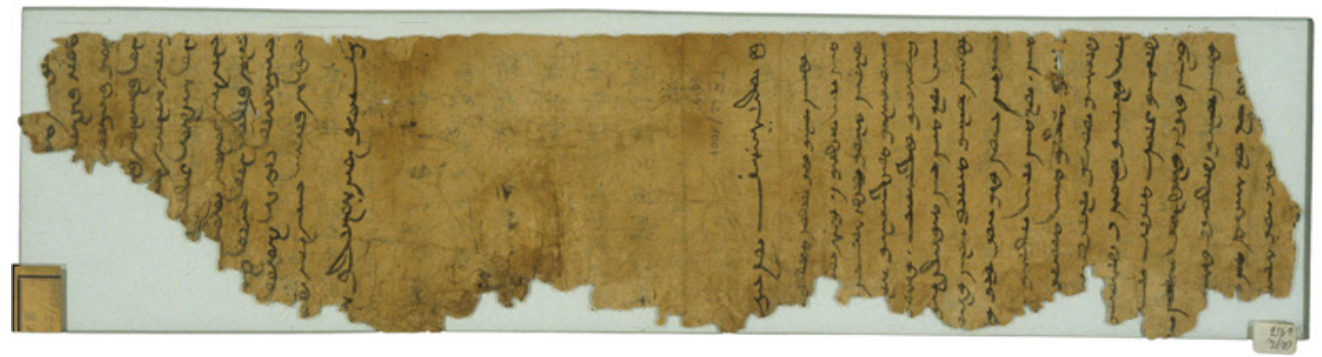

FIGURE 8.1 Fragment of an Old Uyghur translation of the Wutai shan zan 五台山贊 [Praise of Mt. Wutai].

CH/U 6956 VERSO, (C) STAATSBIBLIOTHEK ZU BERLIN - PREUßISCHER KULTURBESITZ, ORIENTABTEILUNG

not only in Old Uyghur translation but also in transcription; that is, in a version that presents the Chinese text in Uyghur script. ${ }^{8}$ Zieme assumes that the Old Uyghur translation has to be dated to the tenth century at the earliest. ${ }^{9}$ Again, the existence of an Old Uyghur version of the Praise of Mt. Wutai (OU udaišansan) is further proof of the close relation between Uyghur and Dunhuang Buddhism. It is therefore not surprising that the religious veneration of pilgrimage to Mt. Wutai (OU udai šan) is expressed in Old Uyghur pilgrim inscriptions found in the caves of the Dunhuang region. ${ }^{10}$

A first insight into Buddhist pilgrimage among the Uyghurs based on their own written sources was presented by Tibor Porció in 2014, under the title, "Some Peculiarities of the Uygur Buddhist Pilgrim Inscriptions." ${ }^{11}$ Within the scope of this study, Porció presents an instructive comparison of the structure between the Old Uyghur colophons, on one side, and Old Uyghur pilgrim inscriptions, on the other. ${ }^{12}$ He concludes:

$8 \quad$ Zieme, "Wutaishanzan Fragments," 224-227.

9 Zieme, "Wutai shan yu Wenshu shili," 119.

10 Matsui Dai 松井太, “Tonkō sekkutsu Uigurugo, Mongorugo daiki meibun shūsei 敦煌石 窟ウイグル語・モンゴル語題記銘文集成 [Uyghur and Mongol Inscriptions of the Dunhuang Caves], in Tonkō sekkutsu tagengo shiryō shūsei 敦煌石窟多言語資料集成 [Multilingual Source Materials of the Dunhuang Caves], ed. Matsui Dai 松井太 and Arakawa Shintaro 荒川慎太郎 (Tokyo: Research Institute for Languages and Cultures of Asian and Africa, Tokyo University of Foreign Studies, 2017), 73: Yo3 Uig 30 män šakyapal

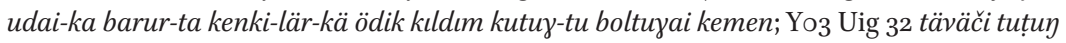
udai-ka barur-ta ödik kıldım sadu bolzun.

Tibor Porció, "Some Peculiarities of the Uygur Buddhist Pilgrim Inscriptions," in Searching for the Dharma, Finding Salvation: Buddhist Pilgrimage in Time and Space, ed. Christoph Cueppers and Max Deeg (Lumbini: Lumbini International Research Institute, 2014), 157-178. 
It goes without saying, the colophons and the inscriptions are, by fundament, the outputs of two distinct activities and of different occasions, therefore they have their own distinctive characteristics, respectively; i.e. they contain elements without a direct counterpart in the other. However, it is not impossible to match, at least tentatively, some of these elements. $^{13}$

As also attested through Old Uyghur colophons, some of the inscriptions are composed in alliterative verses. As an Old Uyghur term, ödik (register, memorandum, memoir $)^{14}$ is used quite often by pilgrims to title their inscription. ${ }^{15}$ Porció appropriately called the pilgrim inscriptions "postscripts to pilgrimage." It is most probably not only due to the local conditions that the length of the preserved Old Uyghur inscriptions varied significantly. In some of them, quite a number of elements known from the Old Uyghur colophons are presentsuch as date, names of pilgrims, motivations, information regarding the transfer of merits, wishes and aims, and, finally, a closing formula. ${ }^{16}$

In the meantime, more and new epigraphic material has been made available, resulting from the ongoing field work in the Buddhist sites on the Northern branch of the Silk Road and in the Hexi region in particular. Multidisciplinary research projects dealing with the manifold materials preserved in the Central Asian collections, while focusing on single Buddhist sites, deliver further information as shown below.

\subsection{The Scope of Old Uyghur Pilgrim Inscriptions}

Only recently, the most comprehensive edition of Old Uyghur and Mongolian inscriptions in the Dunhuang Caves thus far was published by Dai Matsui. ${ }^{17}$ The term Dunhuang Caves (Chin. Dunhuang shiku 敦煌石窟) in the title of this edition is used as a collective term since inscriptions from six different Buddhist cave sites in and around Dunhuang are presented -78 Old Uyghur, seven Mongolian and one Sogdian inscription from 35 caves of the Mogao Caves (Chin. Mogao ku 莫高窟); one Old Uyghur inscription from the Northern Section of the Mogao Caves (Chin. Mogao ku beiqu 莫高窟北区); two Old Uyghur inscriptions from Cishi Pagoda (Chin. Cishi ta 慈氏塔), a single-storey wooden

\footnotetext{
13 Porcio, "Pilgrim Inscriptions," 171.

14 Marcel Erdal, Old Turkic Word Formation: A Functional Approach to the Lexicon, vol. 2 (Wiesbaden: Harrassowitz, 1991), 444.

15 Porció, "Pilgrim Inscriptions," 165-166. See, for instance, the quoted examples in footnote 10.

16 Ibid., 171-172.

17 Matsui, “Tonkō sekkutsu Uigurugo," 1-161.
} 
pagoda near the Mogao Caves; 185 Old Uyghur and six Mongolian inscriptions from 25 Yulin Caves (Chin. Yulin ku 榆林窟); one Old Uyghur inscription from the Eastern Thousand Buddha Caves (Chin. Dong Qianfodong 東千佛洞); and finally, one Old Uyghur and one Mongolian inscription from the Five Temple Caves (Chin. Wugemiao shiku 五個廟石窟) in present Subei Mongol Autonomous County. ${ }^{18}$ Matsui's edition is part of a presentation of the results of a large research project which dealt with the multilingual source materials from the Dunhuang Caves, including Chinese, Tibetan and Tangut inscriptions as well as inscriptions in Brāhmī script and the study of donor portraits. ${ }^{19}$ The huge amount of pilgrim inscriptions representing all important Buddhist languages of that time in this area again underlines the importance of the Dunhuang Buddhist cave complexes within the scope of Buddhist pilgrimage, and with regard to the number of written remains of the Uyghur Buddhists in particular. In addition, some written remains point to an even broader symbolic power and signify a multi-religious society. An Old Uyghur inscription in Syriac script was left in one of the Yulin Caves by a group of people of different faiths. At the end of their visit to this site, they left the inscription in memory of their pilgrimage to Yulin Cave $16 .{ }^{20}$ It is not only the personal names of two of them that clearly identify them as followers of the Christian faith; the terms used in the concluding wishes and closing formulae- "May it be a memory, Amen!" (OU yad bolzun amin) ${ }^{21}$ and "Until all eternity, Amen." (OU apamuka-tägi amin), ${ }^{22}$ - also clearly show a Christian context. ${ }^{23}$

18 Some of the inscriptions are known from earlier editions. All references are to be found at the top of the edited inscription of each.

19 Matsui Dai 松井太 and Arakawa Shintaro 荒川慎太郎, eds., Tonkō sekkutsu tagengo shiryō shūsei 敦煌石窟多言語資料集成 [Multilingual Source Materials of the Dunhuang Caves] (Tokyo: Research Institute for Languages and Cultures of Asian and Africa, Tokyo University of Foreign Studies, 2017).

20 Matsui, "Tonkō sekkutsu Uigurugo," 100 (Y16 Uig 05):

1 bečin yul bešinč ay on beš-tä biz

2 xaču-lug buyan temür $n(\bar{a}) \operatorname{tn}(\bar{\imath})^{\prime} \bar{e} l y(\bar{o}) h(a) n(\bar{a}) n$

3 bo xaču-nıy tag buxar-ına kälip

4 iki kün tezginip üč sorma

5 bir xoyn ašın sökünüp yenä $y a[n] \iota p$

6 bartımızyad bolzun amin

7 apamuka-tägi amin

$21 \quad$ Ibid., line 6.

22 Ibid., line 7.

23 Peter Zieme has already mentioned the existence of this inscription in his paragraph on the scarecely attested Old Uyghur Christian texts from Dunhuang, cf. Peter Zieme, Altuigurische Texte der Kirche des Ostens aus Zentralasien. Old Uigur texts of the Church of the East from Central Asia (Piscataway: Gorgias Press, 2015), 24. 
However, it is possible that the two Christians were in company with a Buddhist, since the personal name on the first position in their inscription, Buyan Temür, could be interpreted as a Buddhist one (OU buyan $<$ Skt. punya, means merit, meritorious deeds). ${ }^{24}$ The group of people characterise themselves as "belonging/originating from Xaču" 25 (OU Kaču < Chin. Guazhou 瓜州), which is Guazhou County (瓜州县, formerly Anxi County 安西县) in the Hexi region. The Yulin Caves are located about 55 kilometres to the south of Guazhou. The pilgrims call the site "the mountain temple of Guazhou" (OU kačuning tag buxarl). ${ }^{26}$ According to Matsui, most of the Old Uyghur and Mongolian pilgrim inscriptions from the Dunhuang region date back to the Mongol period (13th14th c.). The term buxar used in the designation of the Yulin Buddhist cave temples is the Mongolian form of Sanskrit vihära, 'monastery, temple,' which gives further support to this dating. ${ }^{27}$ According to their record, the pilgrims stayed for two days, went around, took three wheat beers or wine (OU sorma) and one meal of sheep meat during their stay, and departed. By means of collecting details like those given in the quoted inscription, we are able to enlarge our knowledge about Uyghur pilgrimage. The edited epigraphic material offers detailed data about the range of pilgrimage to the Buddhist sites in the Dunhuang area. As Matsui summarises, with regard to the present subject:

The situation suggested by the Chinese inscriptions mostly tallies the Uigur and Mongolian inscriptions of the Yulin and Mogao Caves, in which we frequently come across the toponyms of the Gansu region such as Šaču = Shazhou, Qaču = Guazhou and Sügčü = Suzhou, and Yungčang-vu < 永昌府 Yongchang-fu, and T(a)ngut čölgä "the Circuit (čölgä < Mong. čölge = Chin. 路 lu) of Tangut" each once, as the origin of the pilgrims. Besides the toponyms of the Gansu, those of the Eastern Tianshan region such as Qamil or Napčik appear in the Uigur inscriptions. ${ }^{28}$

24 The Old Uyghur term buyan is also attested in a Christian (and Manichaean) context, but most probably is not used as an element of personal names for followers of their religious communities.

25 Matsui, "Tonkō sekkutsu Uigurugo," 100 (Y16 Uig 05), lines 1-2: biz xaču-lug.

26 Matsui, "Tonkō sekkutsu Uigurugo," 100 (Y16 Uig 05), line 3.

27 For further attestations of the term see Matsui, "Tonkō sekkutsu Uigurugo," 142. A similar designation for this Buddhist site, i.e. the 'sacred mountain temple' (OU kutlug tag süm) from Yulin Cave 25, has already been discussed in Porció, "Pilgrim Inscriptions," 172 (fn. 104).

28 Dai Matsui, "Revising the Uigur Inscriptions of the Yulin Caves," Nairiku ajia gengo no kenkyū 内陸アジア言語の研究 [Studies on the Inner Asian Languages: Papers in Honour of Professor Takao Moriyasu on His 6oth Birthday] 23 (2008): 27-28. A small map indicating the listed places is included in Matsui's article (ibid., 28). 
He concludes that "they clearly indicate the Uigurs' active traffic for Buddhist pilgrimage between the Eastern Tianshan and the Gansu region in the Mongol times."29

Uyghur Buddhist pilgrimage also included the site of the White Pagoda (Chin. Bai ta 白塔) on the site of the ancient city of Fengzhou (丰州) (located 17 kilometres from present Hohhot, Inner Mongolia) as is attested from their inscriptions. ${ }^{30}$ The Pagoda of the Ten Thousand Volumes of the Avatamsakasūtra (Chin. Wanbu Huayan jing ta 萬部華嚴經塔) was built under the Khitan Empire (907-1125, in Chinese sources known as Liao 遼), in the Fengzhou Buddhist temple complex. This seven-storey pagoda was erected between 983 and 1031 to serve as a stūpa for sütra storage. According to the recently published Old Uyghur material, we learn about pilgrims originating in Kamıl, Toksın or Čambalık who visited the place. In their often hardly legible inscriptions, which are spread through storeys two to seven, they often report about their wishes and aims; such as, they came in order "to bow to this holy stüpa" (OU bo ıdok stupta yüküngäli kälip), ${ }^{31}$ "to become Buddha because of this merit" (OU bo buyan kücintä burhan bolalım), ${ }^{32}$ so that the inscription "May [...] be seen in future!" (OU kenki körgülük bolzun), ${ }^{33}$ or "to bow to the Noble Mañjuśri”"34 (OU ary-a mančuširika yükünürmän $)^{35}$. These wishes and aims are totally in accordance with those known from formerly published Old Uyghur Buddhist pilgrim inscriptions. ${ }^{36}$ If we take into consideration the historical situation of that area in the Yuan Dynasty (1279-1368, 元), it is no wonder that, again, among the edited Old Uyghur inscriptions, at least two can be related to persons who had a Christian background. ${ }^{37}$

29 Matsui, "Revising the Uigur Inscriptions of the Yulin Caves," 28.

30 Yudong Bai 白玉冬and Dai Matsui 松井太, "Old Uigur Inscriptions of the White Pagoda, Hohhot," Nairiku ajia gengo no kenkyū 内陸アジア言語の研究 Studies on the Inner Asian Languages 31 (2016): 29-77. In total, the two authors were able to decipher and edit twenty inscriptions of different scope.

Ibid., 39 (text J, lines J5-J6).

Ibid., 44 (text R, line R4).

Ibid., 45 (text $\mathrm{T}$, line $\mathrm{T}_{3}$ ).

Skt. Äryamañjuśrí, name of a bodhisattva, i.e. the Bodhisattva of Wisdom.

Bai and Matsui, "White Pagoda," 45 (text T, line T8).

Porció, "Pilgrim Inscriptions," 167-174.

36

37 Bai and Matsui, "White Pagoda," 33-36 (text C) and 42-44 (text Q). For more details with regard to the Christian environment, I would like to refer to the two articles of Pier Giorgio Borbone with more bibliographical data concerning the whole scope of inscriptions in the White Pagoda, which also includes inscriptions in Chinese, Khitan, Jurchen, and Mongolian: Pier Giorgio Borbone, "Syroturcica 2: The Priest Särgis in the White Pagoda," Monumenta Serica 56 (2008): 487-503; Pier Giorgio Borbone, "More on the Priest Särgis in the White Pagoda: The Syro-Turkic Inscriptions of the White Pagoda, Hohhot," in From 
Scholars dealing in detail with the interpretation of the historical significance of the Buddhist caves in the Turfan oasis-like Takao Moriyasu, Koichi Kitsudo and Dai Matsui in their studies on the Bezeklik Caves ${ }^{38}$ — appealed for the strengthening of efforts regarding the philological work on the related inscriptions at these spots, too. ${ }^{39}$ Even in case of the famous wall paintings from the Bezeklik Caves, inscriptions are not limited to the attached cartouches, which provide information about depicted deities, persons or the sponsors of the painting (fig. 8.2).

Peter Zieme recently published the quite numerous inscriptions and scribbles of different hands, which are to be found on the Brāhmana Painting from Bezeklik Cave 20.40 They were spread through the whole painting, using the free spaces. In some few cases, pilgrims even described the purpose of meditation and veneration in verse. ${ }^{41}$ For example, shortly before departing home, a pilgrim transferred the merit that had been earned in the course of his stay to the Good Noble Ones (OU ädgü tägrilärkä buyan ävi[rürmän]).42 More material in the Central Asian collections still needs consideration. Just recently, around 130 pieces of wall inscriptions were re-discovered for detailed investigation in the Museum of Asian Art in Berlin. They belong to the finds of the four German Turfan expeditions between 1902 and 1914, which were excavated

the Oxus River to the Chinese Shores: Studies on East Syriac Christianity in China and Central Asia, ed. Li Tang and Dietmar W. Winkler (Zürich, Münster: LIT Verlag, 2013), 51-65. Moriyasu, "Chronology of West Uighur Buddhism," 191-227; Koichi Kitsudo, "Historical Significance of Bezeklik Cave 20 in the Uyghur Buddhism," in Buddhism and Art in Turfan: From the Perspective of Uyghur Buddhism. Buddhist Culture along the Silk Road: Gandhara, Kucha, and Turfan, ed. Irisawa Takashi (Kyoto: Ryukoku University, 2012), 141-172; Matsui Dai, "Ning-rong 寧戎 and Bezeklik in Old Uighur Texts," Nairiku ajia gengo no kenkyū 内陸アジア言語の研究 Studies on the Inner Asian Languages 26 (2011): 141-175.

39 Kitsudo, "Bezeklik Cave 20," 151; Matsui, "Revising the Uigur Inscriptions," 29.

40 Peter Zieme, "A Brāhmaṇa Painting from Bäzäklik in the Hermitage of St. Petersburg and Its Inscriptions," in Unknown Treasures of the Altaic World in Libraries, Archives and Museums: 53rd Annual Meeting of the Permanent International Altaistic Conference, Institute of Oriental Manuscripts, $R$ [ussian] A [cademy of] $S$ [ciences] St. Petersburg, July 25-30, 2010, ed. Tatiana Pang et al. (Berlin: Klaus Schwarz, 2013): 181-195. Grünwedel's Cave 9 corresponds to Bezeklik Cave 20 today. This wall painting is preserved in the State Hermitage Museum, St. Petersburg. For further studies see, among others, Peter Zieme, Buddhistische Stabreimdichtungen der Uiguren (Berlin: Akademie-Verlag, 1985), 189-192; Matsui, "Ning-rong," 141-175; Zhang, Huiming, "A Study of the Story of the Penance and Elimination of Sins in the Golden Light Sūtra Illustration from the Bezeklik Caves (Focusing on Ty-575 Fragments of the Hermitage Collection)," in Dunhuang Studies: Prospects and Problems for the Coming Second Century of Research, ed. Irina F. Popova et al. (St. Petersburg: Slavia, 2012), 321-332.

41 Zieme, "Brāhmaṇa Painting," 188-189.

42 Ibid., 188 (section 7 (a), line 7 ). 


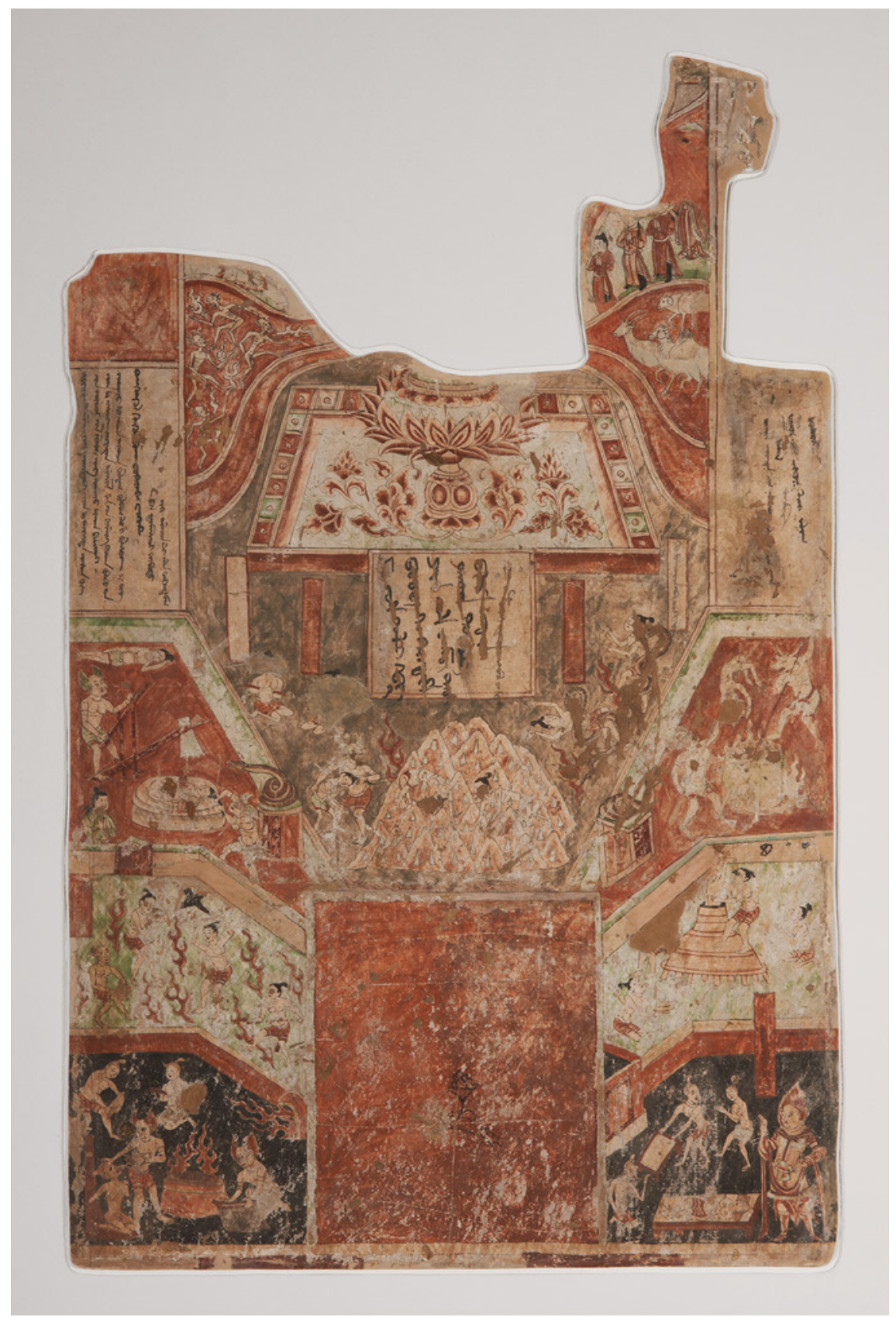

FIGURE 8.2 Buddhist wall painting with scenes from hell and pilgrim inscriptions from Bezeklik Cave 18 (Grünwedel's no. 8).

III 8453, (C) STAATLICHE MUSEEN ZU BERLIN, MUSEUM FÜR ASIATISCHE KUNST 
at different sites. Only a few of them have already been published or catalogued. ${ }^{43}$ The attached finding marks are sometimes very general in their information, ${ }^{44}$ but in cases like 'Chotscho: Ruine K,' 'Sängim: Tempel 1,' 'D (= Dakianusšahri/Kočo), Ruine/Tempel Q', and 'Kumtura, 3. Höhle (Bartus Wohnhöhle), the specific excavation spot is given and may provide a first clue for detecting the holy places for Buddhist pilgrims in the Turfan oasis or neighbouring territories. Like those in the Dunhuang Caves, these inscriptions present multilingual source material in Sanskrit, Tocharian, Syriac, Sogdian, Old Uyghur and Chinese. Some of the inscriptions are preserved as squeezes, black-and-white photographs or re-drawings of the original inscriptions only. Only a comprehensive study of all available remains of the pilgrims' inscriptions from the excavation spots in the Turfan oasis could enhance our knowledge about the 'holy places' and the specific features of Uyghur pilgrimage in this area, with any certainty. ${ }^{45}$ There is no doubt that in order to study the present subject, additional sources, including those in languages other than Old Uyghur, have to be taken into consideration. An excellent example is the Mongolian decree from the Chaghataid Khanate (1220-1370) discovered in the Dunhuang Caves (B163:42), since it reports on the support of Chaghataid authorities for pilgrims on the pilgrimage routes in the Turfan region. ${ }^{46}$

43 Among the published inscriptions, ten are in Old Uyghur language and Brāhmī script from Kumtura and Kizll, which were described and edited in the catalogue volumes of Dieter Maue, cf. voнD 13,9: 201-205 (catalogue nos. 72-77); voHD 13,27: 457-465 (catalogue nos. 210-213). Further on, seven inscriptions in Tocharian and Kharoșțī were published by Georges-Jean Pinault in 1987, cf. Georges-Jean Pinault, "Épigraphie koutchéenne: I. Laissez-passer de caravans, II. Graffites et inscriptions," in Sites divers de la région de Koutcha. Épigraphie koutchéenne = Mission Paul Pelliot (Documents conservés au Musée Guimet et à la Bibliothèque Nationale), ed. Georges-Jean Pinault et al., vol. 8 (Paris: Instituts d'Asie du Collège de France, 1987), 59-196. The Christian Sogdian inscription from the 'Ruine eines großen Klosters' was dealt with by Nicholas Sims-Williams and James Hamilton, cf. Nicholas Sims-Williams et al., Documents turco-sogdiens du IX $X^{e}-X^{e}$ siècle de Touen-houang (London: School of Oriental and African Studies, 199o), 38; Nicholas SimsWilliams, "Sogdian and Turkish Christians in the Turfan and Tun-huang Manuscripts," in Turfan and Tun-huang: The Texts, ed. Alfredo Cadonna (Florence: Olschki, 1992), 58.

44 This general information on the find spot are given in cases like D (= Dakianusšahri/ Kočo), Sängim (T II), Subashi Längär, Bulayık, Ming-öy Kızll, 'MQ Qumtura' (Murtuk/ Kumtura).

45 Further information is to be found among the numerous scribblings of Old Uyghur readers, owners, or sponsors on the manuscripts and block prints preserved in the Berlin Turfan Collection, cf. among others BT XXVI, 45-275; VOHD 13,22: 165-293.

46 For the edition of this Mongolian decree and its interpretation, see Dai Matsui, "A Mongolian Decree from the Chaghataid Khanate Discovered at Dunhuang," in Aspects of Research into Central Asian Buddhism: In Memoriam Kōgi Kudara, ed. Peter Zieme (Turnhout: Brepols, 2008), 159-178. 


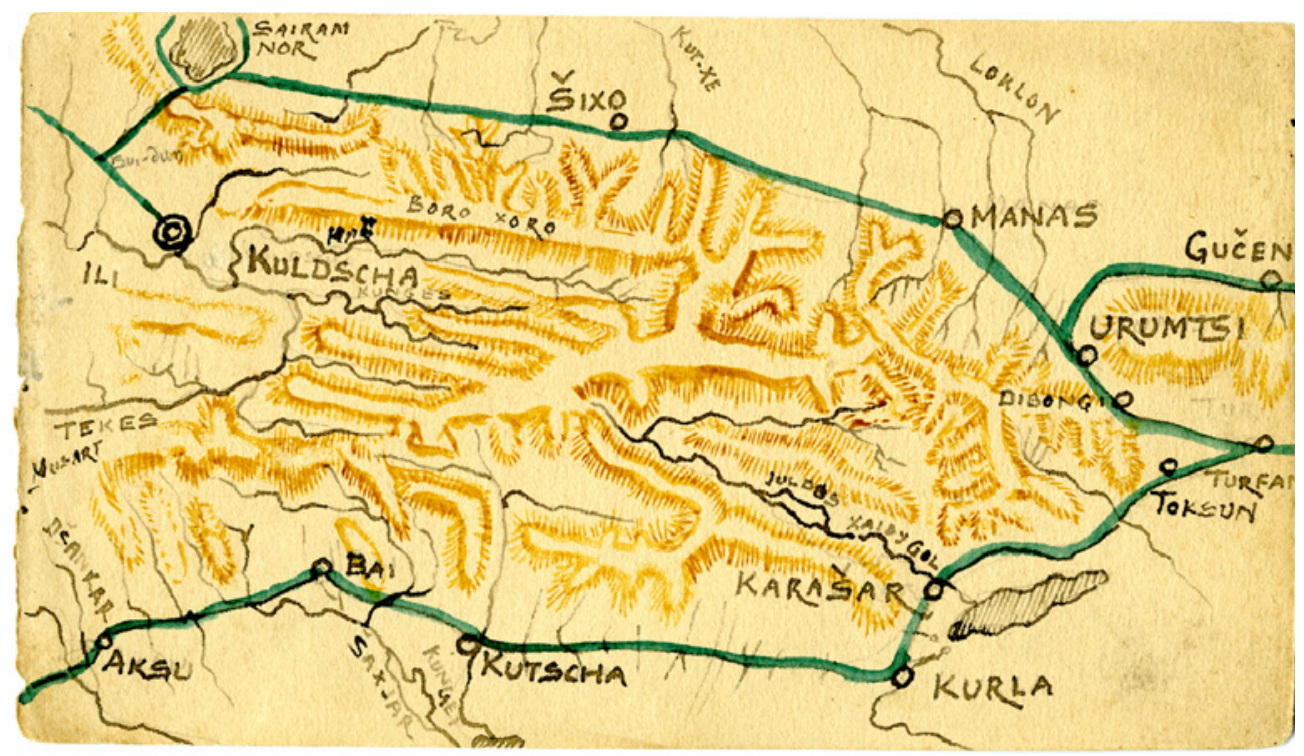

MAP 8.1 Sketch plan drawn by Albert Grünwedel in 1902 showing a route section of the First German Turfan expedition.

TA 6876-24, (C) STAATLICHE MUSEEN ZU BERLIN, MUSEUM FÜR ASIATISCHE KUNST

\section{The Inscriptions of Ruin Q in Kočo-A Case Study of a 'Holy Place'}

In the course of an international project (2014-2015) dealing with the investigation of the various wooden architectural objects from ruin Q in Kočo and their function, all available information concerning the findspot was gathered together. ${ }^{47}$ It came to light that it was not only a Brāhmī inscription on two of the beams of a wooden structure from ruin $Q$ that was preserved, ${ }^{48}$ a whole series of wall inscriptions were found there, as well. Together with the wooden

47 The research project 'Medieval pre-Islamic architecture in Kocho on the Northern Silk Road' at the Museum für Asiatische Kunst, Berlin was supported by the Gerda Henkel Stiftung.

48 The two wooden beams are preserved under the inventory nos. III 4435 b and III 4435c in the Museum für Asiatische Kunst, Berlin. For some figures of these wooden architectural elements, Klaas Ruitenbeek et al., "Ruin Q in Kocho and its Wooden Architectural Elements," in The Ruins of Kocho: Traces of Wooden Architecture on the Ancient Silk Road, ed. Lilla Russell-Smith et al. (Berlin: Staatliche Museen zu Berlin - Preußischer Kulturbesitz, 2016), 110-111. 


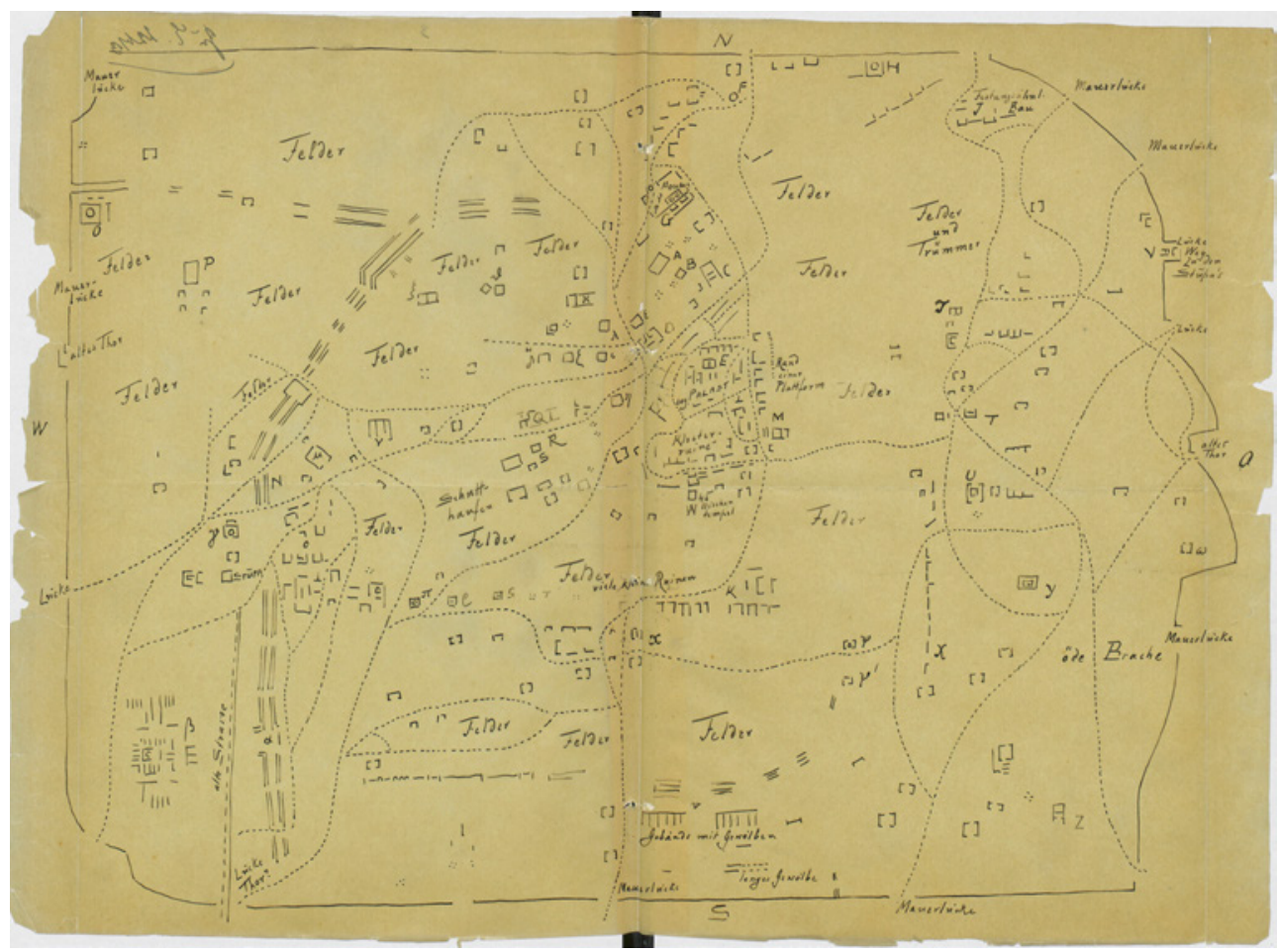

MAP 8.2 Sketch plan of Kočo drawn by Albert Grünwedel (First German Turfan expedition, 1902-1903).

TA 253, (C) STAATLICHE MUSEEN ZU BERLIN, MUSEUM FÜR ASIATISCHE KUNST

elements, they were brought to Berlin by the German Turfan expeditions (map $8.1)^{49}$

According to Grünwedel's sketch plan of the old city of Kočo (map 8.2), ruin $\mathrm{Q}$ is located in the "west of the so-called citadel or Khan's Palace almost in line with ruins $\eta$ (Eta) and $\mu(\mathrm{Mu}) . " 50$

What is of special interest here is that one of the rooms within ruin Q was named 'room with inscriptions' (Germ. Inschriftenzimmer). ${ }^{51}$ In the findings

49 According to the preserved records, ruin Q in Kočo was visited and excavated only during the First German Turfan expedition in 1902-1903. This expedition was led by Albert Grünwedel (1856-1935), an Indologist, Tibetologist and Art Historian with great expertise in Buddhist Studies, who was the first director of the Indian Department at the Berlin Museum für Völkerkunde (1904-1921).

50 Ruitenbeek, "Ruin Q," 103.

51 Ibid. 
inventory, "Inschriftentempel Q" was also used as a designation for this location. ${ }^{52}$ Again, according to Grünwedel's report on the first expedition, "All these inscriptions were located in the inner room at the southernmost part of the terrace. 53

With regard to the present topic, this overall approach to ruin Q cleared the path for looking at this place as a pilgrimage site "because of the role that architecture and objects played as framing devices for the pilgrims' experience at a much wider variety of sites than those that we know from texts." ${ }^{44}$

On the other hand, the importance of the deciphering and interpretation of inscriptions in order to determine the specific function of a building in the past becomes quite clear if we take the following example into consideration. According to the recent results of the Berlin research project, it was not only the square pillar in the middle of the 'room with inscriptions' that served as a replacement for a stūpa, as it was presumed by Grünwedel, 55 "but also the building which houses the pillar."56 Michaël Peyrot, who studied the Tocharian B inscriptions from ruin Q in Kočo in detail, was able to contribute and deliver a further argument as a result of his philological approach, as one of these Tokharian B inscriptions from one wall in the 'room of inscriptions' reads, "whoever has gone into this stūpa." ${ }^{27}$ Being a stūpa, the large quantity of inscriptions left at this place is no longer surprising, since it may be assumed that

$5^{2} \quad$ A copy of a relevant entry of the excavated wooden beams from the original findings list is published in Ruitenbeek, "Ruin Q," 104, fig. 1: Extract of Grünwedel's list of Kočo finds. Museum für Asiatische Kunst, TA 657.

53 Ruitenbeek, "Ruin Q," 106. English translation by Ruitenbeek after Grünwedel, Albert, Bericht über archäologische Arbeiten in Idikutschari und Umgebung im Winter 1902-1903 (München: Verlag der K. B. Akademie der Wissenschaften, 1905), 34.

Wiebke Friese et al., "Introduction: Archaeologies of Pilgrimage," in Excavating Pilgrimage: Archaeological Approaches to Sacred Travel and Movement in the Ancient World, ed. Wiebke Friese and Troels Myrup Kristensen (London, New York: Routledge, 2017), 1.

Grünwedel, Bericht über archäologische Arbeiten in Idikutschari, 173. Also quoted in Ruitenbeek et al., "Ruin Q," 106.

56 Ibid.

57 Michaël Peyrot, "Tocharian B Inscriptions from Ruin Q in Kocho, Turfan Region," in The Ruins of Kocho: Traces of Wooden Architecture on the Ancient Silk Road, ed. Lilla RussellSmith et al. (Berlin: Staatliche Museen zu Berlin - Preußischer Kulturbesitz, 2016), 129. Also quoted in Ruitenbeek et al., "Ruin Q," 106. Unfortunately, because of the existing damage, the context of kiriš in the Old Uyghur inscription from ruin Q with the inventory no. III 1046 of The Museum für Asiatische Kunst, Berlin is not clear. It reads in line 3: [...] YS kiriš bo sägräm vuhar-ka. We may take Clauson's translation into consideration: " 1 kiriş 'entry, way in; incomings, revenue" ED, 747a) and see a certain proximity to the Tocharian B inscription of the fragment with the inventory nо. ВД 757 of The State Hermitage in St. Petersburg, which states in line 2 "Whoever has gone into this stūpa ...," according to Peyrot's above already cited translation. 
ruin Q was regarded as a 'holy place' worthy of pilgrimage. The project's report explains, furthermore:

The inner walls of the "room with inscriptions" were white-washed and from about the middle up to the western wall with the doorway they were covered with Uyghur and a few Chinese inscriptions. ${ }^{58}$

The fact that the attested inscriptions were written in different languages clearly indicates the multi-ethnicity of the pilgrims visiting this place, ${ }^{59}$ and we may suppose that ruin $\mathrm{Q}$ was a major destination for Buddhist pilgrims in the Turfan oasis throughout several centuries.

The attested Tocharian B term pat (stüpa) in one of the Tocharian B inscriptions is especially significant, and Peyrot was able to discover the full meaning of the corrupted Tocharian B inscription by quoting from the Sanskrit Pradakșinagāthā: "Having made a circumambulation of a stūpa, one attains the four noble truths, the [five] faculties and the [five] powers, and the fruit of monkhood."60 The Old Uyghur term sägräm (TochA/B san்krām, Skt. sañghārāma) used in the inscription, with the inventory no. III 386 of the Museum für Asiatische Kunst, Berlin (fig. 8.3), may seem to have a much broader sense than stūpa, but it fits to the attested idea of entering this place-a problem that remains in the interpretation of the Tocharian B inscription, since the attested form patne is a locative singular (i.e. in the stüpa; into the stüpa) ${ }^{61}$

It is well proven, for instance, from the so-called Old Uyghur Sivšidu-Yakšidu manuscripts preserved in the Institut of Oriental Manuscripts, Russian Academy of Sciences in St. Petersburg, that the term sägräm and/or its synonym virhar were explicitely used for the designation of places for worshipping and religious activities. ${ }^{62}$ In the case of the above-mentioned group of texts, it is the abita kur säyräm or the abita kur atl( $\iota) g v(i)$ rhar (i.e. "the Abita-cave temple"), most probably situated at the Toyok Caves and related to the Uyghur

$5^{8} \quad$ Ruitenbeek et al., "Ruin Q," 106. All of that which seemed to be relevant among the detected inscriptions and what was accessible for the expedition was brought to Berlin. These inscribed wall fragments are among the above mentioned re-discovered material. In addition to Matsui (Matsui, "Revising the Uigur Inscriptions," 28), ruin Q attests Chinese pilgrim inscriptions at a Buddhist site in the Turfan region.

59 A small number of inscriptions is also attested in ruin $\mathrm{K}$ in Kočo.

6o For the full reference, see Peyrot, "Tocharian B Inscriptions," 134 note 7.

61 Peyrot, "Tocharian B Inscriptions," 134 note 6.

62 Dai Matsui, "Uigur Manuscripts Related to the Monks Sivšidu and Yaqšidu at "Abita-Cave Temple" of Toyoq," in Journal of Turfan Studies: Essays of the Third International Conference of Turfanological Studies, 2008, Turfan, ed. Academia Turfanica (Shanghai: Shanghai guji chubanshe, 2010), 704 . 


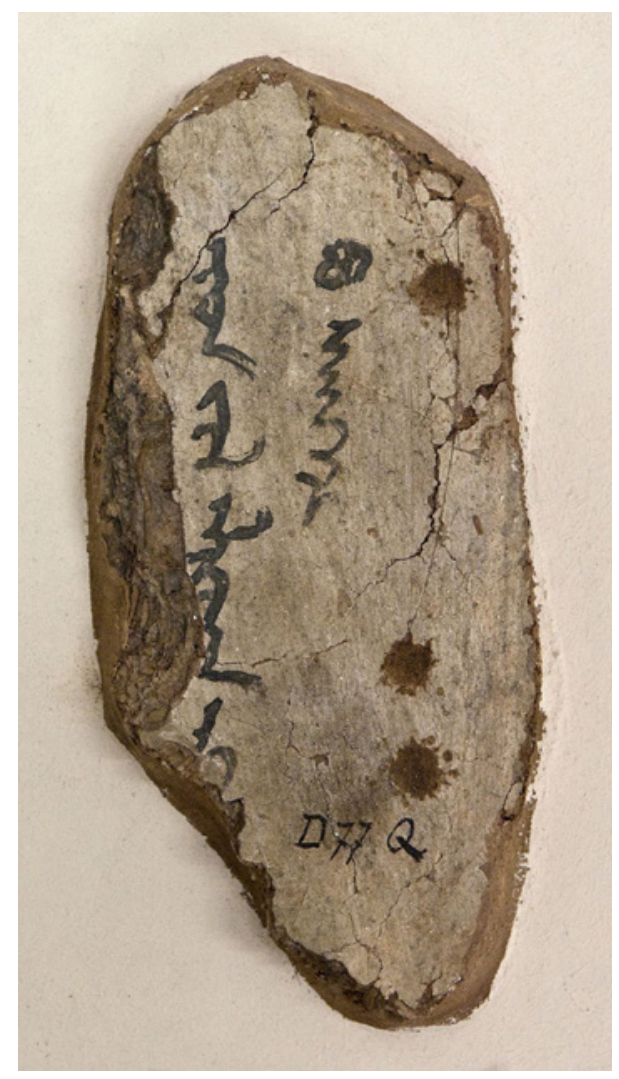

FIGURE 8.3

Old Uyghur inscription from a wall of ruin Q in Kočo.

III 386, (C) STAATLICHE MUSEEN ZU BERLIN, MUSEUM FÜR ASIATISCHE KUNST

Pure Land Buddhism. ${ }^{63}$ Further attestations of the designation of the place could be detected in other Old Uyghur inscriptions from ruin Q as well. ${ }^{64}$

A short poem is part of the Old Uyghur inscription with the inventory no. III 367 (fig. 8.4). ${ }^{65}$ It seems to be a praise on the building and on those who took part in the construction of the vihära, as well as on the efforts of the contemporary people who rebuilt damaged parts. A possible closing formula may be reconstructed as 'all things are unstable' (OU alku nomlar ürl[ügsüz ol]). The author or, at least, the writer of this inscription has šilavanti (Skt. śilavat,

63 As pointed out by Matsui, Old Uyghur texts related to Pure Land Buddhism have been hitherto known mostly from the Buddhist sites of Sängim, Murtuk, Yarkhoto, and the ruins $\alpha$ and $\mu$ in Kočo, cf. Matsui, "Sivšidu and Yaqšidu," 705.

64 Here I would like to thank Peter Zieme for his co-operation with deciphering the inscription. Nevertheless, I have to admit that the deciphering is still in progress, and therefore, the interpretation may still undergo changes.

65 Museum für Asiatische Kunst, Berlin. 


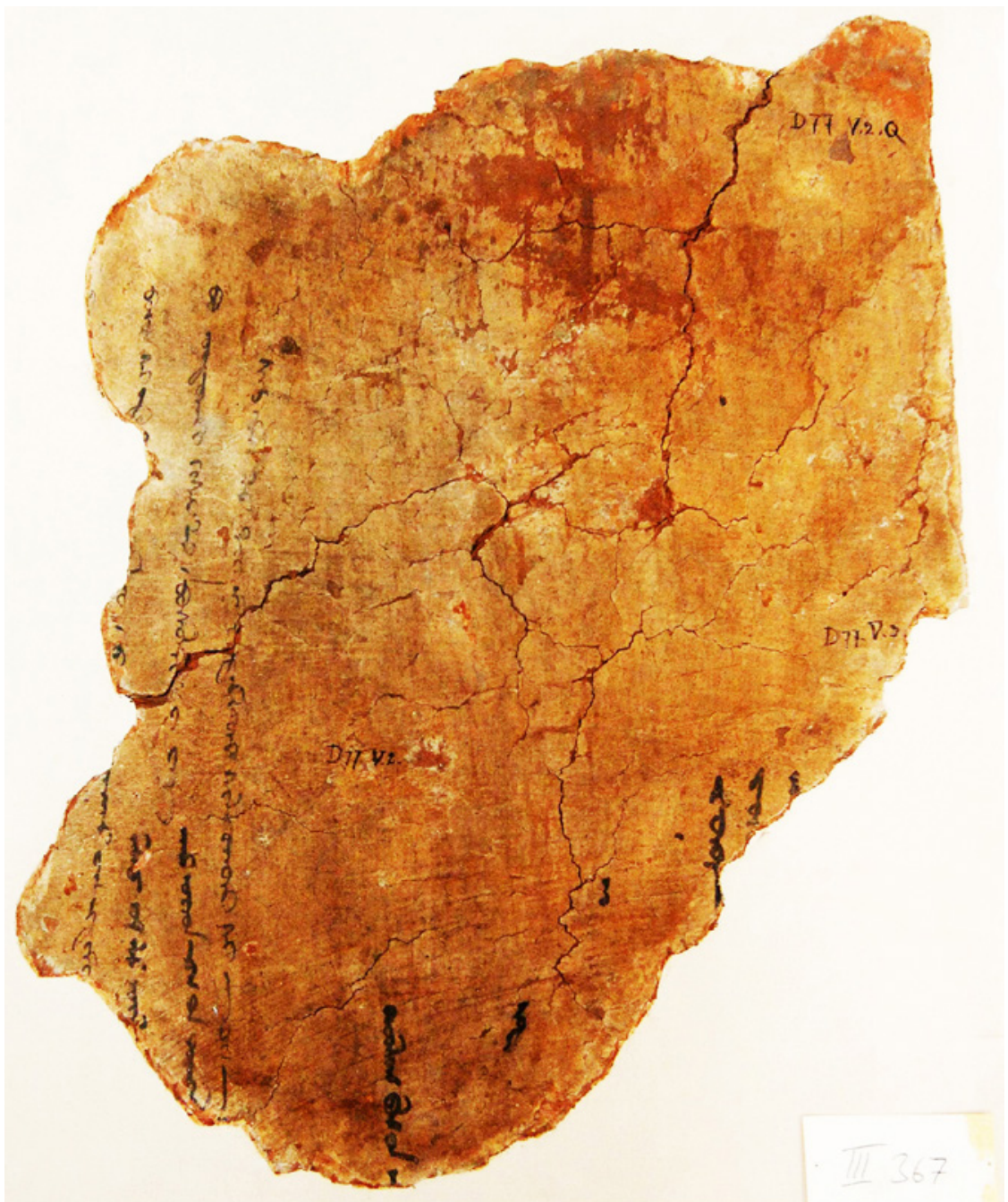

FIGURE 8.4 Old Uyghur inscription from a wall of ruin Q in Kočo.

III 367, (C) STAATLICHE MUSEEN ZU BERLIN, MUSEUM FÜR ASIATISCHE KUNST

possessing moral behaviour) as an element in his name. ${ }^{66}$ The text of this short poem clearly demonstrates the awareness of a long existing history of this stūpa or vihära, which might be one of the factors in it becoming a holy place. And, again according to the the text, there were remarkable efforts to keep

66 Unfortunately, the first element of the personal name is only partly preserved and at the moment no reliable reconstruction can be given. 


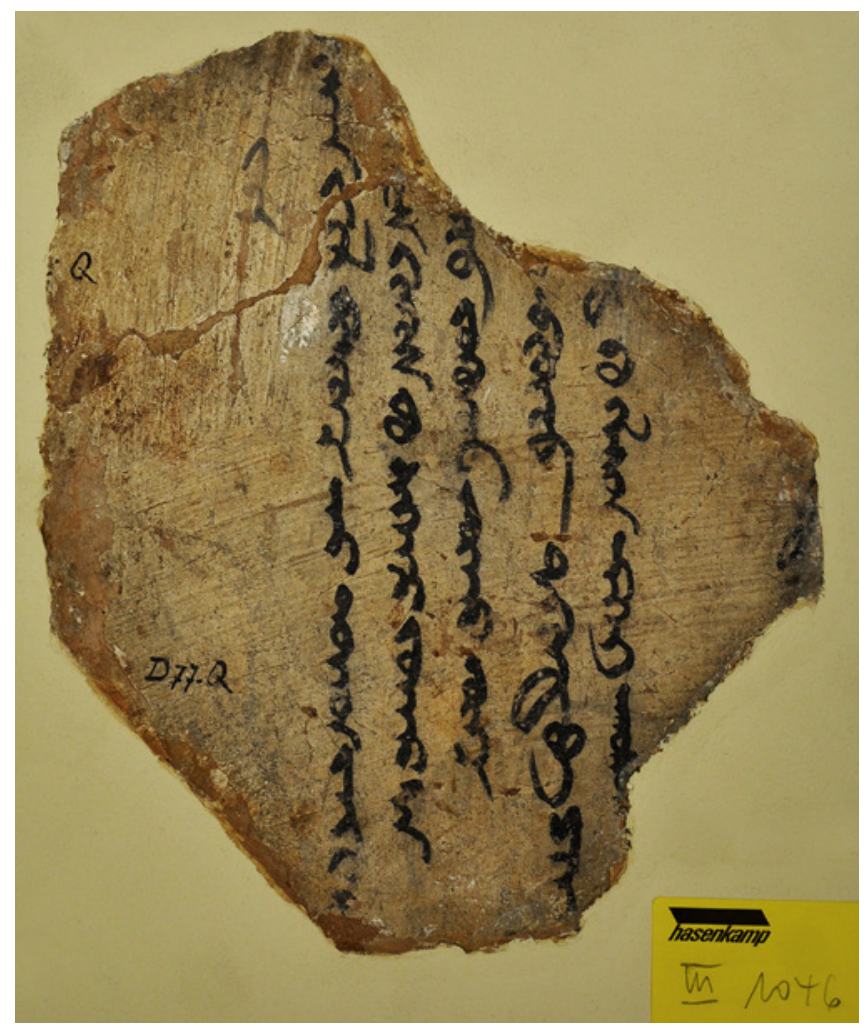

FIGURE 8.5

Old Uyghur inscription from a wall of ruin Q in Kočo.

III 1046, (C) STAATLI-

CHE MUSEEN ZU

BERLIN, MUSEUM FÜR ASIATISCHE KUNST

it like that. But it is not certain whether we may take this as a contemporary report of the pilgrim.

Also, the Old Uyghur inscription already cited above, with the inventory no. III 1046 (fig. 8.5), provides an attestation of the designation of the building as sañghārāma vihāra (OU säyräm vuhar). Looking on the preserved material from ruin $\mathrm{Q}$, we find a very common feature which is present in almost all Old Uyghur pilgrim inscriptions; they start with the date of the record. This is of course given according to the twelve-animal cycle of the Chinese calendar.

The presence of the date seems to be an important indicator that the inscriptions stem from people from the outside. They were written down during their stay at this place or, as shown, shortly before departing from there. It seems to be quite clear that they are not written by the local monastics. This is an important criterion for regarding them as pilgrim inscriptions, since movement - that is, leaving from home (or more precisely, "from one's usual 
everyday-life environment" ${ }^{\prime 67}$ ), arriving at at least one holy place and departing from there in order to return home-is a substantial aspect of pilgrimage. What is remarkable in comparison to other pilgrim inscriptions from the Dunhuang or Yulin Caves, for instance, is that in the current state of research, almost no mentions of the pilgrims' origins have been detected.

This fact raises a question concerning the range of the pilgrimages to this Buddhist site. As far as the material that has been edited up until now is concerned, neither the Old Uyghur inscription in Brāhmī script nor the inscriptions in Tocharian B contain relevant information. But, unfortunately, they are all in a very poor state of preservation. The idea that this absence provides us with a clue to the identification of ruin $\mathrm{Q}$ as primarily being a holy place for pilgrimages limited to local areas cannot be discounted. ${ }^{68}$

The only exception would be the inscription with the inventory no. III 393 (fig. 8.6). ${ }^{69}$ Following the date "Year of the hare, ten[th month], [at the] th[ird day]" (OU tavıšgan yıl on [unč ay ...] ] ü[čüč yayika]), it reads: "I, the ox-herd (and?) camel[-herd] from Koylı" (OU m(ä)n koylı balık-lıg udčı täv[äči ...]).

Even though this place name is attested not only here but also in Old Uyghur and Mongolian documents, it is not localised yet. In the Mongol document from the Berlin Turfan collection, with the catalogue no. MongHT 75 ('Geleitbrief für Kuriere'70), which was also excavated in the ruins of Kočo (= Dakianusšahri $\left.{ }^{71}\right)$, Koylı is mentioned as the place where the document on hand was issued during a stay in winter time (fig. 8.7). ${ }^{72}$

67 Max Deeg, "Buddhist Pilgrimage: An Introduction," in Searching for the Dharma, Finding Salvation: Buddhist Pilgrimage in Time and Space, ed. Christoph Cueppers and Max Deeg (Lumbini: Lumbini International Research Institute, 2014), 5.

68 On this topic, see Deeg, "Buddhist Pilgrimage," 8.

69 Museum für Asiatische Kunst, Berlin.

70 BT XVI, 182. The shelf no. of the fragment in the Berlin Turfan collection is Mainz 869.

71 The finding signature of the damaged document is T II D 306 . In the records of the Second German Turfan expeditions, this document is mentioned in the findings list of the expedition from the excavation spots of Dakianusshahri, Sängim and Chikkan Köl up to February 17th, 1905: [T II D] 306 Uig. Dokument, 'Ruine a. gr. Kl.' Because of the great similarity in the script, there are often mistakes in the identification of the language in the very early stage of the discovery. The abbreviation of find spot probably has to be interpreted as 'Ruine am großen Kloster.'

72 The editors of the catalogue of the Mongolica, preserved in the Berlin Turfan collection, presented the reading Qunglu for the place name in MongHT 75, line 10, cf. BT XVI, 182. Resulting from the results of an inspection of the original text, the former reading, 'Qongli,' presented by Michael Weiers, should be preferred, cf. Michael Weiers, "Mongolische Reisebegleitschreiben aus Čayatai," Zentralasiatische Studien 1 (1967): 41-42. The vocalisation of the first syllable remains an unanswered question. 


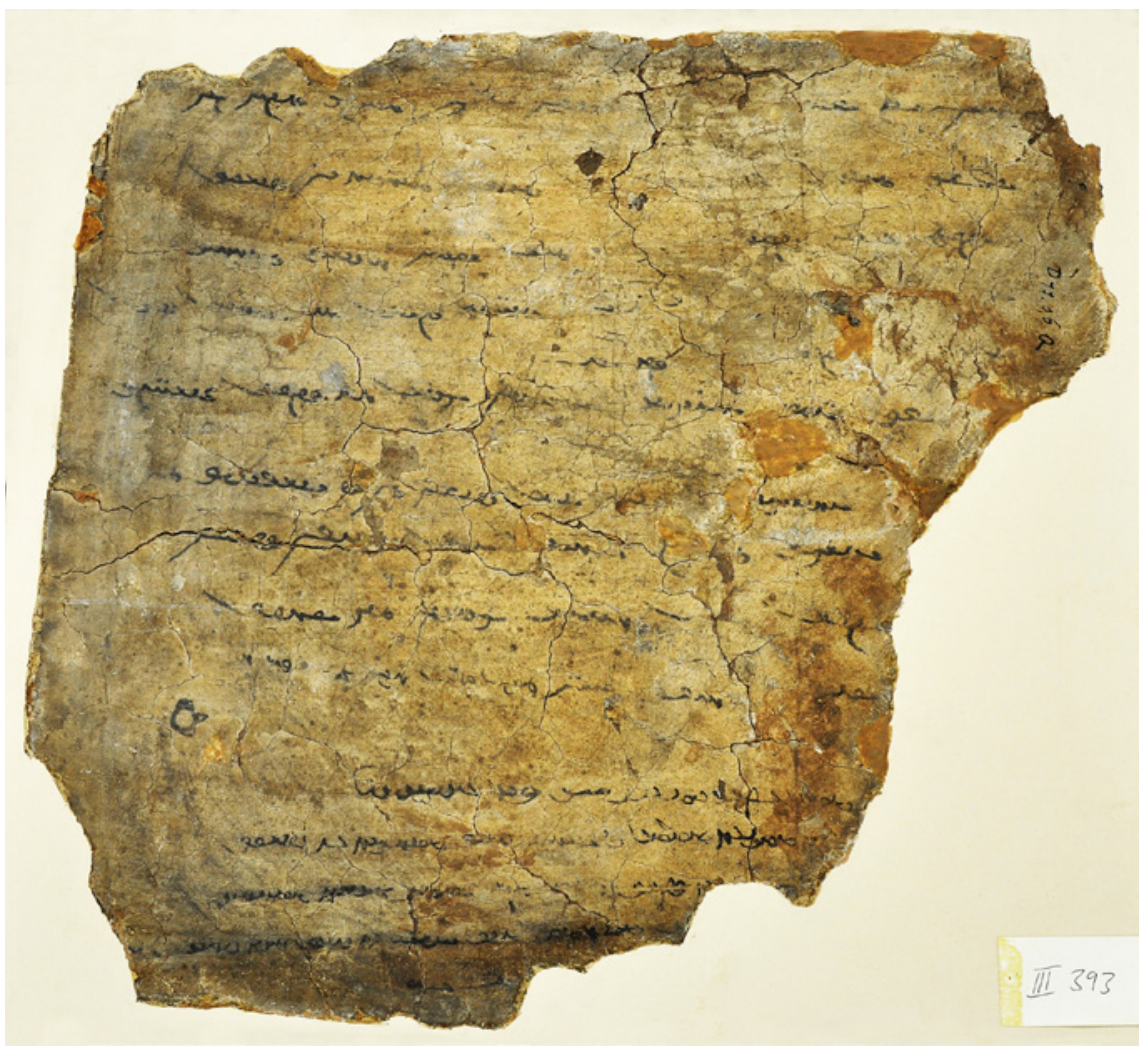

FIGURE 8.6 Old Uyghur inscription from a wall of ruin Q in Kočo.

III 393, (C) STAATLICHE MUSEEN ZU BERLIN, MUSEUM FÜR ASIATISCHE KUNST

From the land sale contract *U 9341, we learn that a canal, named Kargač or Karanč, is located in Koylı (OU koylı-takı kargač/karanč ögän). ${ }^{73}$ Unfortunately, in Dai Matsui's new study on "Old Uigur Toponyms of the Turfan Oases," this place name is not mentioned. ${ }^{74}$ The interpretation of the personal names

$73{ }^{*} \mathrm{U} 9341$ line 03 . This document belongs to those lost in World War II in the Berlin Turfan collection. It is only preserved as a photograph in the Arat estate in Istanbul, cf. voHD 13,28: 143 (catalogue no. 111). A further attestation is to be found in an Old Uyghur manuscript of the Berlin Turfan collection, with the inventory number $\mathrm{Ch} / \mathrm{U} 7145$, which is related to the system of postal relay stations, cf. voHD 13,21: 194-195 (catalogue no. 189: $\mathrm{Ch} / \mathrm{U} 7145 \mathrm{v})$.

74 Dai Matsui, "Old Uigur Toponyms of the Turfan Oases," in Kutadgu Nom Bitig: Festschrift für Jens Peter Laut zum 6o. Geburtstag, ed. Elisabetta Ragagnin et al. (Wiesbaden: Harrassowitz, 2015), 275-303. 


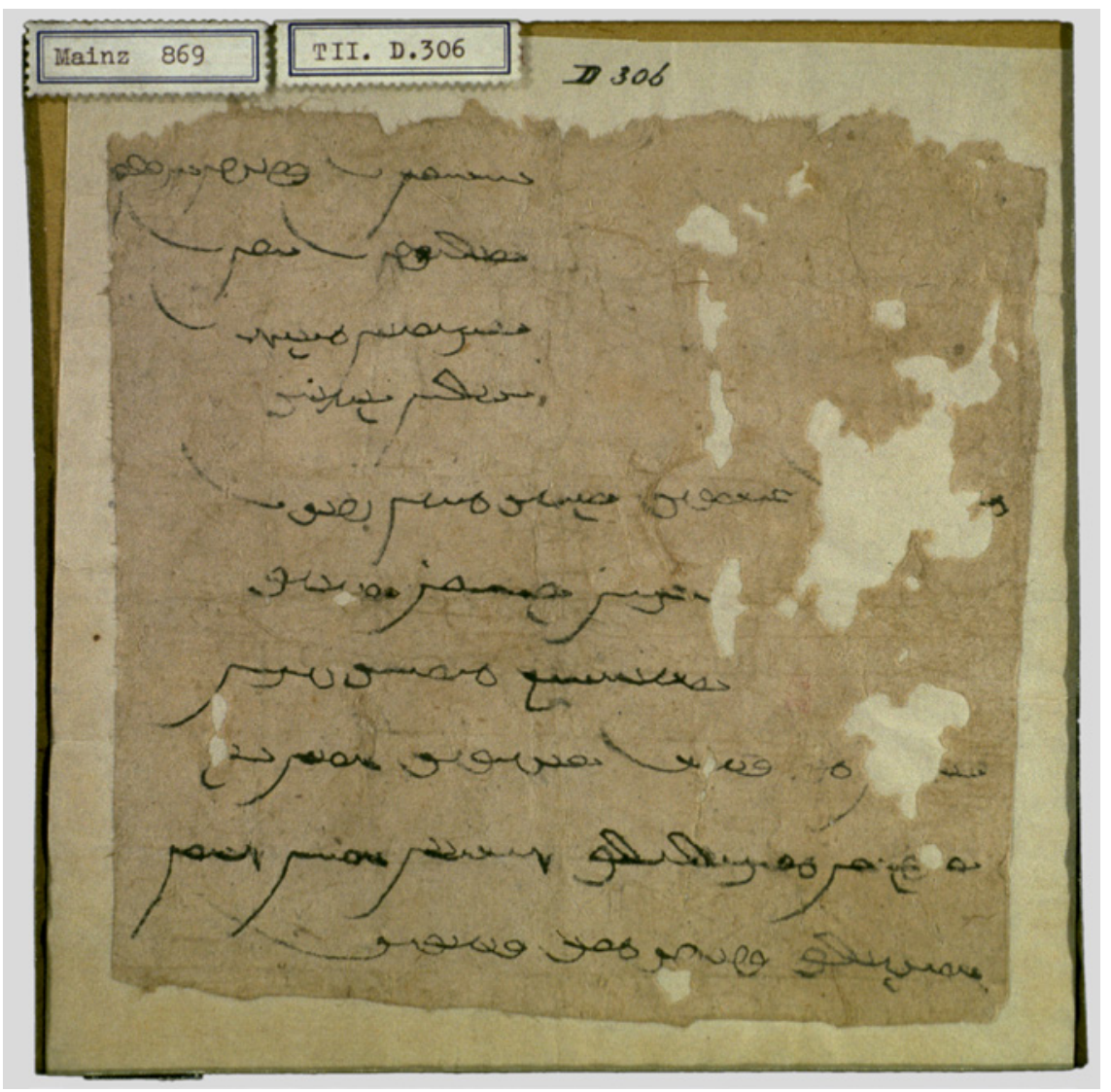

FIGURE 8.7 Mongolian document ('Geleitbrief für Kuriere’) preserved in the Berlin Turfan collection.

MAINZ 869, CATALOGUE NO. MONGHT 75, (C) STAATSBIBLIOTHEK ZU BERLIN

- PREUßISCHER KULTURBESITZ, ORIENTABTEILUNG

mentioned in the inscription is not completely clear either, since the elements $u d \check{c} \iota$ (or read oțačc?) and täväčci can be interpreted as professional titles ('cattle breeder,' 'camel breeder') as well as proper names. ${ }^{75}$ Most interestingly, the arrival of a caravan at the sägräm virhar is mentioned further in the text lines and may point to the existence of interrelations between the routes of the caravans and the routes of pilgrims in the Turfan oasis. And it seems to be quite reasonable that these are not interrelations between the routes only. It is also highly probable that pilgrims joined these caravans because of the adverse

75 The existence of a further name element cannot be excluded, but the following part of the inscription is not preserved. 
conditions in this area, at least for a certain section of their journey. Pilgrimage, that is, the process of travelling, is dependent on socio-economic conditions. Buddhist laymen involved in the trade or postal relay systems, who visited Buddhist sites on their routes in order to venerate these holy places, are not among those who are to be counted as Buddhist pilgrims in the strict sense of the term. Additionally, it is attested by the recent research on the Old Uyghur documents that cattle breeders, the above mentioned udčl, are part of the postal relay system; just as $u$ d ulags ('ox ulag') are part of this system. ${ }^{76}$

In the inscription III 393, a section concerning the wishes resulting from the punya earned by visiting this Buddhist site (i.e. the stüpa) is present as well. The Buddhist intention of being "liberated from the cycle of reincarnations through the vehicle of Buddhahood" (OU burhan [kutllg k] ölök üzä sansar ämgäktin ozup) is expressed in this particular case. ${ }^{77}$ The conclusion phrases in the inscription III 1046, already cited above several times, reads, "May merit come. May pain disappear!" (OU [ä]dgü kälzün ämgäk ärtzün), ${ }^{78}$ phrases that are quite similar to those known from the preserved pilgrim inscriptions in the Dunhuang Caves. ${ }^{79}$ These text parts clearly stand for the main intentions of Buddhist pilgrimage: the acquisition of religious merit by visiting holy places and, finally, to attain liberation from the cyclic existence (Skt. samsāra, OU sansar).

The group of pilgrims who produced the inscription III 379 (fig. 8.8) describe themselves as students or teachers (OU bošgutčllar). ${ }^{80}$ Unfortunately, the reading of the two preceding and slightly damaged words is still not completely certain, but in the present context "divine Buddhist teaching" (OU $t(\ddot{a})$ yri šazin, Skt. śäsana $)$ is a an option. ${ }^{81}$ The personal names which are listed as members of this group, after the given date, show a clear affiliation to the Buddhist community; for instance, Tilik Ačari, ${ }^{82} \mathrm{D}$ (a)rmaḍaz (Skt. dharmadāsa, slave of the dharma), Karunadaz (Skt. karuṇādāsa, slave of karuṇa), and Buyan Tämür. ${ }^{83}$ Further studies are necessary for a complete understanding of this

\footnotetext{
76 Cf. BT (forthcoming), UlRego6-1o.

77 III 393, lines 9-10.

78 III 1046, line 6.

79 Matsui, "Tonkō sekkutsu Uigurugo," 56 (no. 86: M465 Uig 04), 90 (no. 170: Y12 Uig 13), 100 (no. 196: Y16 Uig 04), 106 (no. 207: Y19 Uig o2), 136 (no. 281: Do2 Uig o1).

8 o $\quad$ III 379 , line 3 .

$81 \quad$ III 379, line 3 .

82 The Old Uyghur personal name element ačari is a Buddhist title given to Buddhist monks acting as teachers (Skt. ācārya).

83 Old Uyghur personal names with the element daz (Skt. dāsa) are discussed in Peter Zieme, "Samboqdu et alii: Einige alttürkische Personennamen im Wandel der Zeiten," Journal of Turkology 2.1 (1994): 119-133.
} 


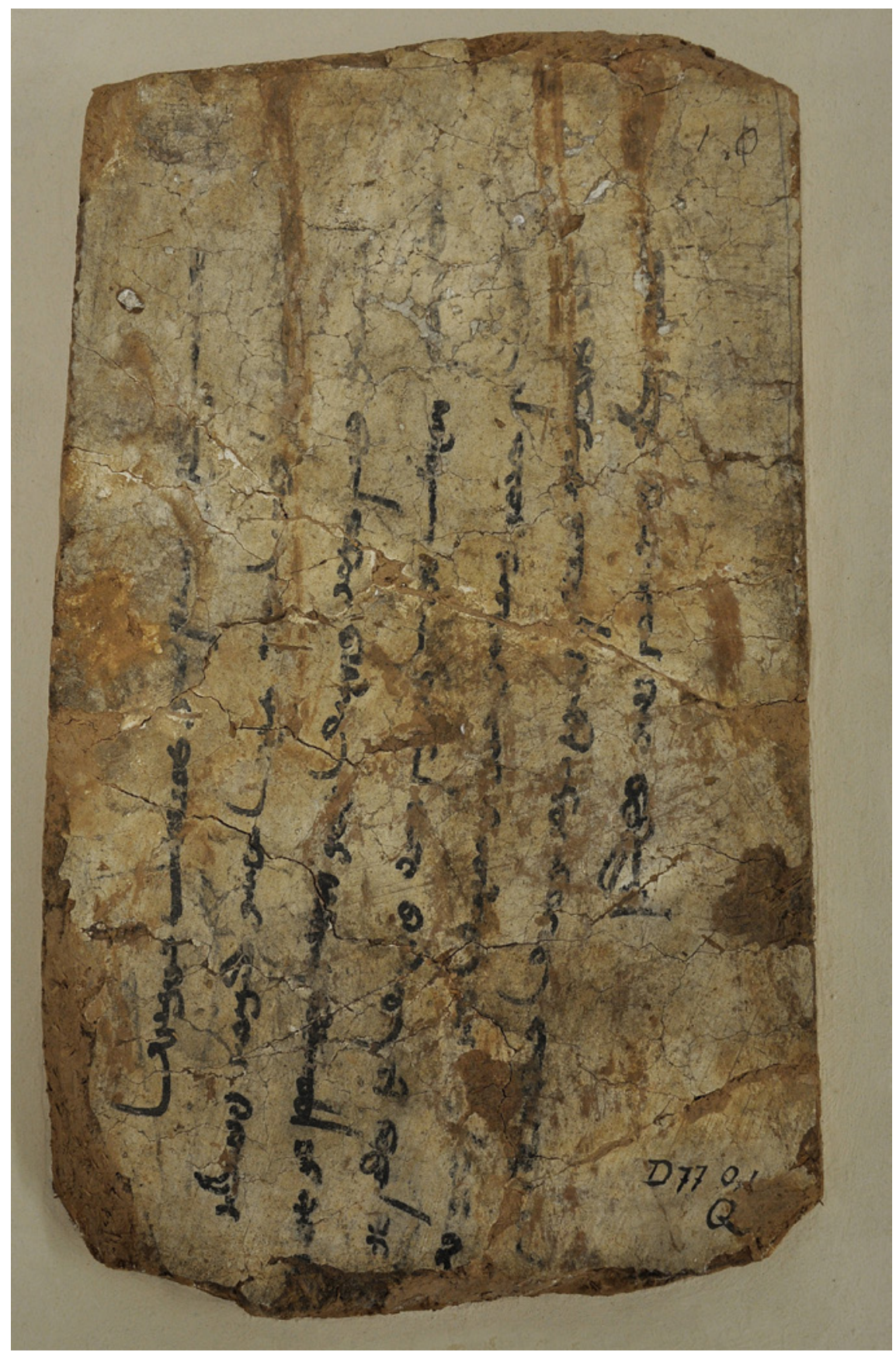

FIGURE 8.8 Old Uyghur inscription from a wall of ruin Q in Kočo.

III 379, (C) STAATLICHE MUSEEN ZU BERLIN, MUSEUM FÜr ASIATISCHE KUNST 
inscription, but another part of the group probably consists of the people with Kulun Ky-a Tümän Bägi at the head. If my interpretation is correct, the inscription was written on behalf of quite a large group of people. ${ }^{84}$

Some results of the interdisciplinary research project 'Medieval pre-Islamic architecture in Kocho on the Northern Silk Road' provide a clue for the approximate time span during which ruin $\mathrm{Q}$ was a holy place for Buddhist pilgrims in this area. Gudrun Melzer, who was studying the Sanskrit inscription on the preserved wooden beam from ruin Q (fig. 8.9), came to the conclusion that the script corresponds to type vi (alphabet $\mathrm{u}$ ) of Northern Turkistan Brāhmī, used between the 7 th to 14th centuries. ${ }^{85}$

According to Dieter Maue, that was also the case for the Old Uyghur inscription in Brāhmī script on the above cited wall fragment with the inventory no. III 319. ${ }^{86}$ According to Melzer, a great majority of the published Sanskrit manuscript findings from Kočo written in this type of script have "a probable (Mūla-) Sarvāstivāda background." ${ }^{87}$

Peyrot dates the Tocharian B inscriptions from ruin $Q$ to the eighth century or later. ${ }^{88}$ The very cursive style of the inscription in Old Uyghur script gives us a tentative indication of a fairly late date for the Old Uyghur inscriptions from ruin Q; that is, the Mongol period (13th-14th c.).

Taking the aspect of architecture into account, it is possible to add that the wooden elements from ruin Q, with their unique lavish painting, date from the tenth to eleventh centuries. ${ }^{89}$ This is also the case for the painted designs on

84 It is most probably only by chance that a person named Karunadaz (Karunāāāsa) is also mentioned in the Old Uyghur inscription in Brāhmī script on the wall fragment III 319 from ruin Q (Maue, Alttürkische Handschriften, Teil 1, 204-205: catalogue no. 76), as well as the Sīlavān Dharmadāsa (Brāhmī: dha ma da-z śi la va nti) in the inscription of the wall fragment III 419 (Maue, Alttürkische Handschriften, Teil 1, 205: catalogue no. 77) from the Ming-öy Kızl Caves (Chin. Kezi'er Qianfodong 克孜尔千佛洞) near Kumtura. These names are fairly widespread among Uyghur Buddhists. According to Maue, the Brāhmī script of the inscriptions corresponds to the alphabet u of Lore Sander's palaeography, cf. Lore Sander, Paläographisches zu den Sanskrithandschriften der Berliner Turfansammlung (Wiesbaden: Franz Steiner, 1968), 182-183, plates 29-41.

85 Gudrun Melzer, "Appendix: A Fragmentary Sanskrit Inscription on a Wooden Beam from Ruin Q (III 4435 B)," in The Ruins of Kocho: Traces of Wooden Architecture on the Ancient Silk Road, ed. Lilla Russell-Smith et al. (Berlin: Staatliche Museen zu Berlin - Preußischer Kulturbesitz, 2016), 123-126. According to Melzer, the content of this inscription is a collection of epithets of the Buddha, cf. Melzer, "Appendix," 123-124. For a figure of the Sanskrit inscription, see Melzer, "Appendix," 123, fig. 38.

86 See footnote 83.

87 Melzer, "Appendix," 124.

88 Peyrot, "Tocharian B Inscriptions," 128.

89 Ruitenbeek et al., "Ruin Q," 114b, $122 \mathrm{a}$. 


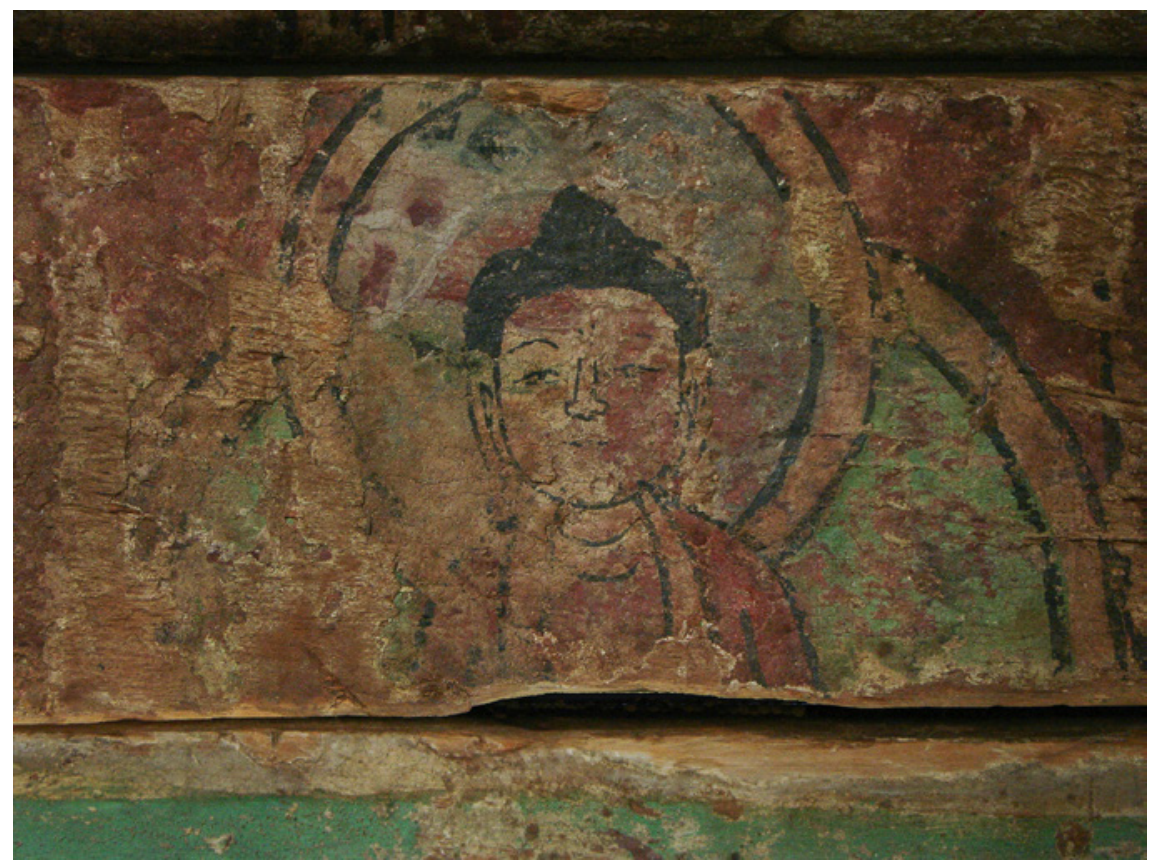

FIGURE 8.9 Buddha image painted on beam in Kočo.

III 4435C, (C) STAATLICHE MUSEEN ZU BERLIN, MUSEUM FÜR ASIATISCHE KUNST/MARTINA RUNGE

them, which represent the typical style of the period. ${ }^{90}$ Ruitenbeek calls the reconstructed wooden structure an "amalgamation of Chinese wood architecture and Central Asian earth architecture." ${ }^{11}$ According to him, "the Chinesestyle wooden architecture of Kočo reflects older Tang-dynasty styles, perhaps going back to the Xizhou period." 92

From the results of the multi-disciplinary approach ${ }^{93}$ presented above, it is possible to state that ruin $\mathrm{Q}$ with its former function as a stupa occupied an

$90 \quad$ Ruitenbeek et al., "Ruin Q," $119 b$.

$91 \quad$ Ibid., 109a.

92 Ibid., 115 b.

93 The volume quoted above, "Excavating Pilgrimage," with contributions of scholars exploring archaeological evidence, including architecture and "the material footprint of activities undertaken by pilgrims" (Wiebke Friese et al., "Introduction," 1 ) is a good example for this topic from another area of the ancient world; i.e. Classical and Hellenistic Greece, the Roman Empire and Late Antiquity. 
extraordinary position at the site of Kočo and was a holy place worthy of pilgrimage. ${ }^{94}$

With regard to the main topic of this contribution, I would like to close with a short quotation of my honoured teacher from one of his recently published articles:

While standard expressions or dates are even decipherable in the worst cursive script, reading names and other more essential issues of such inscriptions is much more difficult. ${ }^{95}$

Therefore, a comprehensive study of all available material concerning the Uyghurs and Buddhist pilgrimage in the Turfan region as well as the full range of the pilgrim's movement would be worth discussing in a project in its own right. 96

94 For further remarks on the topic see also Deeg, "Buddhist Pilgrimage," 20.

95 Zieme, "Brāhmaṇa Painting," 193.

96 An comprehensive edition of the recently re-discovered and aforementioned Old Uyghur wall inscriptions from the Museum of Asian Art is in preparation. 